\title{
Refugee Women in London: The Experiences of Somali Women
}

\author{
Rosemary Sales and Jeanne Gregory
}

\begin{abstract}
Abotract
This article is based on interviews with tweenty Somali refugee women living in London. The interviews focused mainly on the women's experiences since arrioing in Britain and their hopes and expectations for themselves and their children. The article explores the extent to which gendered roles have been reinforced or renegotiated as a result of their move to Brituin. Formost of the women, their lives in Somalia were bused primarily within the household. Some had worked in professional occupations and had combined public and private roles through the support of female kin. For all the women, exile brought financial, social and legal insecurity and none was in permanent employment. Some, however, found new independence and confidence in exile, and have been able to renegotiate relationships from a more potverful position. Others have lost status and self-esteem, and those who had been able to combine caring roles with professional work in Somalia have found this impossible in Britain. The study exposed the gaps between the women's skills and experience and the work they have been able to find. There is an urgent need for Somali speakers in teaching, medicine and social work, but Somali qualifications are not recognized in Britain. This demonstrates the urgency of a comprehensive strategy, including training, for refugee resettlement in Britain.
\end{abstract}

\section{Précis}

Cetarticle est busésur un ensembled'entreoues avec vingt fermes somaliennes refugices a Londres. Les entrevues por-

Rosemary Sales, Ph.D., is Principal Lecturer in the School of Sacial Science at Middlesex University, London, Unitad Klngdom.

Jemne Gregory, Ph.D., is Professor of Gender Studles and Head of the Gender Research Centre at Middlesex University, London, United Kingdom. tent principalement sur l'expdrience vécue de ces femmes depuis leur arrive en Grande-Bretagne, et leurs espoirs et attentes pour elles-memes et pour leurs enfants. L'article explore dans quelle mesure leur rôle de sexage a été réaffirmé ou renégocié consécutivement d̀ leur déplacement vers la Grande-Bretagne. Pour La majorité de ces fenmes, la vie en Somalie se passait principalement d la maison. Certaines d'entre-elles avaientexercédes occupations professionnelles et avaient combiné róle public et rôle privế dans leur activité de support des membres de leur famille de sexe fiminin. Pour toutes ces femmes, l'exil a amené l'insécurité surles plans financier, social et légal, et aucune d'entre elle ne détient un emploi permanent. Certaines cependant, ont trouvé une nouvelle independance et une nouvelle confiance en soi dans l'exil, et sont paroenues d renégocier leur relation maritale depuis une position affermie. D'autres ont perdu leur statut et leur estime de soi, et celles qui arrivaient d̀ combiner rôle familial et activité professionnelle en Somalie n'y sont par parvenues en Grande-Bretagne. L'étude présente le hiatus accusé entre les savoir-faire et l'expérience de ces fermes d'une part et le travail qu'elles sont arrivees d trouver. $I$ y a un besoin criant de somaliens en enseignement, en médecineet en travail social, mais les qualifications somaliennes ne sont pas reconnues en Grande-Bretagne. Ceci tend d̀ démontrer l'urgence d'une strategie globale, incluant la formation, aux fins de la réinstallation de réfugiés en Grande-Bretagne.

\section{Introduction}

Britain has no permanent, central program for refugee resettlement. On arrival, refugees may be given ussistance with immediate reeds such as housing and interpretation by specialist organizations and refugee community groups (Duke 1996). Access to more permanent support is however limited and uneven. Like other refugees, mostSomalis settle in London where there are established communities. Several thousand Somalis live in Waltham Forest, concentrated in the less prosperous areas. Most live in private rented accommodation, often sharing with other families in grossly overcrowded conditions. Some have been housed by the council, but recent legislation has prevented local authorities from housing asylum seekers in permanent accommodation.

Most Somali refugees spend several months or years in refugee camps in Africa. Those who manage to reach Britain are generally from the wealthier classes, who have the resources to purchase tickets. Many use false documents and may have difficulty proving their identity in Britain. Only one woman in our study had "Convention" status. Mosthad "Exceptional Leave to Remain (ELR)"1 status, while others were awaiting decisions by the Home Office. ELR confers no right to family reunion, and for many, separation from husbands and children is the main problem they face in exile. This uncertainty makes it difficult for them to put down roots and to plan a future.

This paper is based on a small-scale study of the experiences of resettlement of Somaliwomen refugees living in London, including interviews with twenty women carried out in early 1997.2 All of the women arrived in London between 1990 and 1996, and most now live in the Borough of Waltham Forest in East London. The women left Somalia as a result of the civil war, and most had lost members of their close family.

Semi-structured interviews were carried out with these women. These interviews varied in length and depth. Some took place in the women's homes and others in the offices of community organizations. The first two were carried out in English and the others in Somali with an interpreter, although some women also spoke partly in English. There were often interruptions, particu- 
larly with the interviews in community centres, where the interpreter was called on to deal with emergencies, which meant that it was not always possible to probe all the issues we wished to raise. The women often sought our advice on specific problems relating to education, health and housing, and we attempted to advise where we were able.

The interviews focused mainly on the women's experiences since arriving in Britain and their hopes and expectations for themselves and their children. We were interested in the extent to which gendered roles had been reinforced or renegotiated as a result of their move to Britain. There has been a considerable amount of research on the specific problems faced by women refugees (Forbes Martin 1992; Osaki 1997; UNHCR 1995) and the difficulties they experience in gaining refugee status (Adjin-Tettey 1997; Crawley 1997; Kuttner 1997). Another theme which has emerged, however, is that women seem to find it easier than men to adapt to changed status (Kay 1989; Summerfield 1993; Buijs 1993; Refugee Council 1996). It is often men who lose most status as a result of flight. Unable to work and to fulfil their traditional role of "breadwinner," they may also have lost a public political role as well. In contrast, many women refugees experience new opportunities. Often, for the first time, they are acquiring independent income through benefits or employment. These patterns are evident in our study, although the experiences of the women varied considerably.

Our contacts with this group of women have been built up over several years during which we have been studying the resettlement needs of refugees (Sales and Gregory 1996; Duke, Sales, and Gregory 1998). Two women who were highly respected within the community acted as interpreters and introduced us to our interviewees. Mariam was a volunteer advice worker for a local women's community organization, and Ferhat was a gynaecologist in Somalia who was also known for hercampaigning work against Female Genital Mutilation (FGM). Their involvement established an atmosphere of trust and friendship which was essential not only due to the sensitive nature of much of the subject matter, but because some of the women's residence status was insecure, and they were suspicious of outsiders.

\section{The Findings}

All the women were or had been married; eighteen had married in Somalia, and two married Somali men in Britain. Ten were here without their husbands; three of the men died as a result of the war, and seven were still in Somalia or neighbouring countries. The remaining eight women had husbands in Britain, although three of these marriages had broken down. Most had suffered a serious decline in their standard of living as a result of be coming refugees. Only one was in secure employment, and most were managing with severely limited resources.

The first interviews were with Mariam and Ferhat. Unlike most other respondents, they had played a significant role in public life before the war. Their own activities, and the repercussions they suffered as a result, were decisive factors in their decision to leave.

Mariam, a science graduate, had been active in a women's group in Mogadishu which helped women displaced due to the civil war. With no welfare system, and the economy largely destroyed, the organisation attempted to find shelter, food and clothing for them. When the war spread to the capital, Mariam continued her work.

She was not interested in taking sides:

The warlords hated me because wouldn't support them. They claimed I was diverting my energies and those of the other helpers away from the war effort. Because we worked with everybody, regardless of which clan they belonged to, they said we were undermining support for the war. I had a lot of enemies. They used to threaten my life.

These threats eventually forced her to flee, leaving her three children behind. She was married at the age of thirteen, but had separated from her husband many years ago. She came to Britain on her own, and was the only woman interviewed with full refugee status in her own right, which she won after an appeal against the original Home Office decision to refuse it.

Ferhat's father was a politician, and she told us her family was unusual in favouring education for girls as well as boys. When the civil war started, Ferhat continued to work in the hospital, but she too made enemies and had to leave:

They used to say to me, "You

shouldn't trea t this person, he's from

the wrong clan." I said that I'm a doctor, and I will treat anybody who needs my help. They used to try and threaten me, and it became very dif-

ficult to work there.

Neither Ferhatnor Mariam was able to use their qualifications in this country. They both did voluntary work for the community, and were studying in order to be able to take up paid work. Some of the other women also had higher education and professional qualifications. They, like Ferhat, had been able to combine work and family in Somalia through the support of the extended family. Fatima had been a nurse working as a rural health worker. She left Somalia when her husband was killed.

Farida worked as a chemist in a factory until the outbreak of war, despite having two young children. These women had been able to combine their public and private roles through support from other women rather than sharing domestic tasks with men. While all said their husbands were supportive of their public work, they had not changed the gendered division of labour in the household.

Most of the other women saw their lives as primarily based within the household, and spoke of a sharp divisionof gender roles as the norm in Somalia. This divergence of experience is similar to the differences found by Kay (1989) in her study of Chilean refugees, whom she describes as either "publicprivate" or "private" women. Thesedifferences have led to varied experiences in exile, although the relations between their previous and current roles are complex. 


\section{Gender Relations in Exile}

As civil society in Somalia began to disintegrate, it was women who tended to keep the households together. They would grow, make and sell anything they could, whereas men would have found such activities demeaning. In Britain; whether they are with their husbands or alone, women take on the main burden of keeping the family together and dealing with landlords, teachers, social security, doctors and lawyers.

In her comparative study of Somali and Bengali women in London, Summerfield found that Somali men appeared to suffer from depression more frequently than Somali women, and, they appeared to be less in control of their lives (Summerfield 1993, 83). Several women in our study expressed concern for their husband's mental and physical well-being. The loss of self-esteem and living standard associated with refugeestatus had come as a severe blow. According to Ferhat, Somalimen often withdrew rather than take on new challenges. Her own husband had had a highly paid government job in Somalia. She told us about him:

He feels depreseed and isolated. He sits at home and reads newspapers.

He hardly ever goes out. He has a problem with his hearing which has gotten worse, but he won't get it looked at.

Another woman, Leila, whose husband had been anengineer recounted to us:

When he sees buildings like the ones he used to build, he just stops and stares at them. He would love to be able to do that kind of work. His asthma [a stress related disease] has become chronic since we came here.

Many men seek consolation with other Somali men, often meeting to smoke qat. ${ }^{3}$ This provides a temporary escape butaggravates their problems in the longer run since it makes them too lethargic to seek work, and often irritable and depressed afterwards. Some seeksolace in religion and often become more observant. Mariam said:

They think, "if I die I'll go to heaven." It helps them when they get de- pressed about conditions here. The men have problems with employment, they have lost their rights and status. They often take to religion, and become fanatical.

For some women, exile has led to marriage break down. Aysha had four daughters and no sons, and had lost seven children in childbirth. Sons are important to a Somali wife, as her connection to her husband's lineage is through her sons. Ferhat believed that Aysha's "failure" to bear sons was a major factor in her marriage dissociation. In Somalia, the husband might have resolved the situation by taking another wife without necessarily divorcing Aysha. She herselfbelieved that her marriage would have ended anyway.

Ambara's husband had also left her. Though she was reluctant to go into details, it emerged that the husband had been violent and the children were relieved to seehim go. Although the man's loss of status in exile is often blamed for domestic violence (Refugee Council 1996), ironically, this case involved the only husband in full-time paid employment. Mariam claimed that domestic violence is common in the community:

Women are not listened to in the community, there is no respect. Religion is used as an indirect weapon. There is a lot of violence against women, and if they leave, they may be accused of bringing shame on the family. Men don't want women to be able to do things for themselves. Lots of families separate in England, because the women change, they become more independent.

Some of the younger women appeared to be making more demands on their husbands. Ikram had married a Somali man in Britain and had two young children. Hewas not prepared to help with the children, and spent his time with other men rather than looking for work. She decided she could manage better withouthim, and was now separated. Another woman, Feyrus, who had also gotten married in Britain said:

Life is hard for Somali men. The way we are brought up, sisters help the man, doing all his cooking and wash- ing. If he doesn't marry, he knows he will be looked after by his mother and sisters. It is very difficult for them to adapt.

Her young child was being looked after by her husband during the interview. She said he had found this difficult at first, but she felt strong enough to insist that he took his share to allow her to do voluntary work and study. Other studies have shown that divorce is high among Somali women in Britain as women have found more independence, and feel that they do not need to depend on a husband (Ali 1997).

Divorce is frowned upon in Somalia but is by no means unknown. Ferhat said that many young girls run away from their firsthusbands because of the pain and fear associated with sexual intercourse, a consequence of female genital mutilation (FGM). FGM (sometimes referred to as circumcision) is almost universal in Somalia, and the severest form, infibulation or Pharaonic, is the most common (Maxamed 1989). The sensitivity of this subject meant that it was not easy to pursue with our interviewees, particularly at the first meeting. It was sometimes brought up by the women themselves. At one meeting with eight women of varying ages and education allexpressed dislike of the practice, and talked disparagingly of theinsistence of Somali men that their wife's vagina be sewn up tightly after childbirth. Mariam said, "We have been spoiled, but we donot want our daughters to be. They claimed it had to be done for religious reasons, but now we know it was just to control us."

This issue is likely to remain a major source of division within the community, and the health implications are increasingly confronting a variety of professionals, such as health and social workers. Many women with young daughters have resolved not to have them circumcised, and it appears that it is women (together with their mothers) who make the decision. Nevertheless, it is still common for daughters to be sent to Africa to be circumcised, since the practice is illegal in Britain; and Somali boys often return to the refugee camps to 
seek brides, to ensure that they secure a "clean" wife. Uncertainty about how long they will remain in Britain has implications for the continuation of this practice. Many Somalis fear that if their daughters are not circumcised, they would be ostracized from the community, and this would be even more intense in Somalia.

Mariam was the most outspoken in her criticism of the way religion is used to justify the oppression of women. The other women in the study all identified themselves strongly as Muslims, although the extent of their observance varied. These variations were visible in the way they dressed, although all of them covered their heads in public. Ferhat is devout, but claimed that supporters of FGM had distorted Islam since the practice is not required in the Koran.

Community groups play an important role for most of the women. Those with better language and skills are able to use these to support other members of the community. Those with less English rely heavily on the groups for help in interpreting, negotiating with officials, and pursuing their claims with the Home Office. There are five Somali organizations in the borough, including two women's groups, and these reflect ethnic divisions within the community. One women's group was set up because the women felt excluded from the maledominated association. They began meeting in each other' shomes until they were given permission to use local authority premises twice a week. The men who used the same premises on different days tried at first to prevent the women from having access. But the women's group continues to thrive, offering a range of advice and support to women. Men's response to this success is often ambivalent. Mariam, who took a leading role in establishing the group, told us, "The men say to me, 'we like what you are doing for the community, but keep away from our wives. We don't want them to become independent like you."'

Although the groups are divided on ethnic lines, women have tended to be more open to working with women from other groups, and the women we interviewed were keen to reduce these divisions. They collaborated in community and education projects, and friendships spanned the two groups.

\section{Employment}

Refugees and asylum seekers, particularly women, face multiple barriers to employment both through theiruncertain legal status, and the racialized and gendered structures of the labour market. Only one of the women we interviewed was in permanent employment, and a few had found casual paid work as interpreters or in cleaning and other low status occupations. This is in line with national research (Carey-Wood et al. 1995) and a local survey which found high unemployment among refugee women, and that most of those employed felt theirjobs did not make use of their skills and qualifications (London Borough of Waltham Forest 1994). Many felt that employers had stereotyped views about Somali women, and that they were discriminated against because of their dress. Although many had skills that were urgently needed to support the community, for example, as teachers and health workers, none of the women with professional qualifications was able to work in the same area in Britain. Their qualifications were not recognized and the conversion courses were too expensive to be a realistic possibility for most refugees.

For women who had left high status occupations, the loss of self-esteem was hard. Fatima, who had been a nurse, said, "My work was very important in my life. Now, when we go to a hospital here, they think we are nothing, we don't know anything."

For most Somali women, preoccupation with the day to day problems of looking after their children, and adapting to a strange, often hostile, environment made employment a remote possibility. Uncertainty about legal status, and the hope of a return to Somalia also made it difficult for them to make long term commitments to education and training for employment. Nearly all the women had attended English classes, attaining various degrees of proficiency, and some had undertaken other forms of education and training. While they hoped for paid employment, they expected that their skills and experience were more likely to be used in a voluntary capacity. Many claimed that women were more adaptable and willing to take on new roles including work oflower status than they had been used to. Fatima and Ferhat, for example, are now taking a health promotion course and plan to extend their voluntary work within the community.

Feyrus, who had no qualifications or employment experience in Somalia, saw life in Britain opening up more possibilities for her. She had done language and computer courses in London, and worked voluntarily in a community centre. She planned to study full-time:

Women don't work outside the home in Somalia. In Britain, both [husband and wife] need to work because you need both incomes. prefer to work. You know what is happening next and feel more independent. If anything goes wrong, it is your choice.

\section{Relations with Children}

For many, their children represented a future which they felt they had lost for themselves. Their children's progress often shifted their perceptions of their future, and the possibilities of returning to Somalia if peace were to come. Most hoped to return, but as Saida said, "We are in a foreign country, we have to try very hard. If we went back to Somalia, the children would have to start again. I feel their education is here."

Those who were themselves wellducated use their skills to help their children, although the lack of books, the demands of family members, and overcrowding sometimes made this difficult. Fatima told us about her boy at secondary school, "He is a very bright boy. I teach him science and spend three or four hours with him each night. I am afraid of him getting lazy."

While many children, especially the younger ones, had settled in and were achieving well at school, others felt a painful change in their relations with 
their children. Several parents of teenagers felt they were getting out of control. Khadiza said:

Children in Somalia have to listen to their parents. Sometimes I feel children here are spoilt. I don't feel they are my children, it worries me. I can't speak English well and I don't know whether they are talking about me.

Children often see their parents as less powerful in the new society and lose respect for them, while parents have become more dependent on their children to act as interpreters for them. Using children as interpreters can cause problems because children may be involved in discussions which their parents would rather they do not hear. Zamzam said, "My older daughter interprets forme at the doctor's, but sometimes I don't want to let her know what I am feeling. I get so worried and I don't want her to know how bad things are."

Conclusion

Our interviewees presented a complex picture in terms of gender roles. Some found new independence and confidence in exile, and have been able to renegotiate relationships from a more powerful position. Others, however, have lost status and self-esteem, and those who had been able to combine caring roles with professional work in Somalia have found this impossible in Britain. These women have, nevertheless, shown remarkable adaptability, taking on a variety of roles to support the community and working to build a future for themselves and their children.

The study has exposed the gaps between the women's skills and experience, and the work they have been able to find. There is an urgent need for Somali speakers in such areas as teaching, nursing and social work, but few have the resources to undertake the necessary training to allow them to work in Britain. This demonstrates the urgency of a comprehensive strategy for refugee resettlement which would allow refugees to make their fullest contribution to their own community and to the wider society.
Notes

1. ELR is a form of temporary residence status granted on humanitarian grounds. It involves fewer social rights than Convention status. Family reunion is possible only afterfouryears' residence and is subject to afterfouryears' residenc
stringent conditions.

stringent conditions.
The study was funded by a small grant from Middlesex University Faculty of Socia Science.

3. Qatisalegaldrugwhichischewed,mainly by men in groups. Its damaging effects have led to calls from the community to ban its importation.

\section{References}

Adjin-Tettey, E. 1997. "Defining a Particular Social Group Based on Gender." Refuge 16, no. 4.

Ali, E. 1997. "Our Strength Comes with Us: Somali women and Gender Relations in London." Paper presented to the Annual Conference of Women's Studies Network, June.

Buijs, G., ed. 1993. Migrant Women: Crossing Boundaries and Changing Identities. Oxford; Providence, RI: Berg.

Carey-Wood, J., K. Duke, V. Karn, and T. Marshall. 1995. The Settlement of Refugees in Britain. London: HMSO.

Crawley, H.1997. Women as Asylum Seekers: A Legal Handbook. London: Immigration Practitioners' Association and Refugee Action.

Duke, K. 1996. "The Role of the Community Group in Refugee Resettlement in Britain." New Community 22, no. 3, 461-78.

Duke, K., R. Sales, and J. Gregory. 1998. "Refu

gee Resettlement in Europe." In Refugees,

\section{Refuge}

\section{Canada's Periodical on Refugees}

Published six times a year by the Centre for Refugee Studies, York University, Toronto.

\author{
Available from:
}

Centre for Refugee Studies, York University

Suite 333, York Lanes, 4700 Keele St. Toronto ON Canada M3J IP3

Bmail refuge@yorku.ca

http://www.yorku.ca/research/crs 